\title{
UPAYA MENINGKATKAN MINAT BELAJAR SISWA MELALUI PEMBERIAN BIMBINGAN BELAJAR MENGGUNAKAN MODEL DISCOVERY LEARNING PADA KELAS IV SD NEGERI 23 BATARA KECAMATAN WARA KOTA PALOPO
}

\author{
Dwilia1), Bellona Mardhatillah Sabillah²), Satriawati³), Muh. Khaedar ${ }^{4}$ ) \\ 1 PGSD, Universitas Megarezky \\ dwiliadwilia21@gmail.com \\ 2 PGSD, Universitas Megarezky \\ bellona.sabillah@gmail.com \\ ${ }_{3}^{3}$ PGSD, Universitas Megarezky \\ satriawati.01@gmail.com \\ ${ }^{4}$ PGSD, Universitas Megarezky \\ khaedar.muh32@gmail.com
}

\begin{abstract}
Dwilia, 2021. An Efforis ti Inrease Students' Interest in Learning through Providing Tutoring Using the Discovery Learning Model in class IV 23 Batara Elementary Schoool Wara District Palopo City, supervised by Bellona Mardhatillah Sabillah and Satriawati.

This study aims to increase students' interest in learning using the discovery learning model in grade IV 23 Batara Elementary School, Wara District, Palopo City. The type of research used id classroom action research and uses a quantitative approach. Data collection techniques using questionnaires, observation, and documentation.

The results of the research in cycle I and cycle II. In the first cycle, interest in learning was $68,24 \%$, with an average score of $80,85 \%$ in the high category. While in the second cycle with a percentage of $80,60 \%$ and an average value of $95,95 \%$ in the very high category. To conclude, the increase in student interest in learning can be seen, which has increased significantly.
\end{abstract}

Keywords: Learning Interest, Model Discovery Learning

Abstrak. Dwilia, 2021 Peningkatan hasil belajar IPA melalui metode resitasi pada siswa kelas V SD Inpres Borong Jambu II Kota Makassar. Dibimbing oleh Bellona Mardhatillah Sabillah, S.Pd., M.Pd dan Satriawati, S.Pd., M.Pd.

Upaya Meningkatkan Minat Belajar Siswa Melalui Pemberian Bimbingan Belajar Menggunakan Model Discovery Learning Pada Kelas IV SD Negeri 23 Batara Kecamatan Wara Kota Palopo yang dibimbing oleh Bellona Mardhatillah Sabillah dan Satriawati. Penelitian ini bertujuan untuk meningkatkan minat belajar siswa menggunakan model Discovery Learning pada siswa kelas IV SD Negeri 23 Batara Kecamatan Wara Kota Palopo.

Jenis penelitian yang digunakan yaitu Penelitian Tindakan Kelas dan menggunakan pendekatan kuantitatif. Teknik pengumpulan data menggunakan Angket, Observasi, dan Dokumentasi.

Hasil penelitian pada siklus I dan siklus II. Dimana pada siklus I terdapat minat belajar dengan persentase 68,24\% dengan nilai rata-rata 80,85\% dengan kategori tinggi. Sedangkan pada siklus II terdapat minat belajar dengan persentase 80,60\% dengan nilai rata-rata 95,95\% berada di kategori Sangat tinggi. Sehingga dapat dilihat pada peningkatan minat belajar siswa yang mengalami peningkatan yang signifikan.

Kata kunci: Minat Belajar, Model Discovery Learning 


\section{PENDAHULUAN}

Sekolah merupakan suatu dasar pendidikan untuk membekali siswa berupa kemampuan membaca, menulis, dan berhitung semata, tetapi harus dengan mengembangkan potensi yang ada pada siswa baik potensi secara mental,sosial dan spiritual. Sekolah dasar harus memiliki visi mengembangkan manusia beriman dan bertakwa kepada Tuhan Yang Maha Esa, berakhlak, mulia, sehat, beriman, cakap, kreatif, mandiri, dan menjadi warga negara yang demokrasi serta dapat bertanggung jawab Susanto (2019:12).

Pendidikan pada umumnya selalu berintikan bimbingan. Sebab pendidikan bertujuan untuk agar anak didik menjadi kreatif, produktif dan mandiri. Artinya pendidikan berupaya untuk mengembangkan individu anak. Segala aspek diri anak didik harus dikembangkan seperti dalam intelektual, moral, sosial, kognitif, emosional. Bimbingan dan konseling adalah suatu upaya dalam membantu perkembangan aspek-aspek tersebut menjadi optimal, harmonis dan wajar. Sehubungan dengan hal itu, guru sebagai pendidik merupakan salah satu unsur pendidikan yang mempunyai peran penting di dalam mewujudkan tujuan dari pendidikan. Sebagai pendidik yang selalu berkecimpung dalam proses belajar mengajar pastilah menginginkan proses belajar yang efektif dan efisien. Maka dari itu penguasaan materi saja tidaklah cukup, seorang guru harus menguasai berbagai strategi pengajaran yang tepat dan sesuai dengan materi yang akan diajarkan Hikmawati (2010:35).

Aktivitas dalam belajar bagi setiap individu, IQ yang tinggi belum tentu menjamin keberhasilan belajar. Salah satu faktor penyebab kesulitan adalah karena tidak adanya minat seseorang terhadap suatu mata pelajaran yang akan menimbulkan kesulitan belajar. Terhadap mata pelajaran yang akan menimbulkan kesulitan belajar. Belajar yang tidak ada minatnya mungkin tidak sesuai dengan bakatnya, kebutuhan, kecakapanya atau tidak sesuai dengan tipe-tipe khusus anak yang menimbulkan problem pada dirinya. Karena itu pelajaran pun tidak perna terjadi pada otak, akibat timbulnya kesulitan belajar. Ada tidaknya minat terhadap suatu pembelajaran dapat dilihat dari cara anak mengikuti pelajaran, lengkap tidaknya catatan, memperhatikan garis miring tidak dalam pelajaran itu. Dari tanda-tanda itu seseorang petugas diagnosis dapat menemukan apa penyebab kesulitan belajarnya, yang disebabkan karena adanya minat atau boleh disebab yang lain Slameto (2013:111-112).

Berdasarkan SK Mendikbud No.025/01/1956 mengenai tentang teknis ketentuan pelaksanaan jabatan fungsional dan angka kreditnya, menyatakan bahwa "bimbingan dan konseling adalah pelayanan bantuan untuk siswa baik secara perorangan maupun kelompok agar mampu mandiri dan berkembang serta optimal dalam bidang bimbingan belajar dan bimbingan karir melalui berbagai jenis layanan dan kegiatan". Salah satu layanan utama yang dilaksanakan guru pembimbing adalah layanan penguasaan konten. Konten merupakan isi dari layanan penguasaan konten, yaitu satu unit materi yang menjadi pokok bahasan atau materi latihan yang dikembangkan oleh konselor dan diikuti atau dijalani oleh individu peserta layanan. Layanan penguasaan konten merupakan layanan bantuan akan yang diberikan kepada setiap individu (sendiri-sendiri atau maupun bantuan kelompok) untuk menguasai kemampuan atau kompetensi tertentu melalui kegiatan belajar. Penguasan konten diharapkan setiap individu mampu memenuhi kebutuhannya serta mengatasi suatu masalah-masalah yang dialaminya. Layanan penguasaan konten terfokus pada dikuasainya konten oleh para peserta yang memperoleh layanan. Selain daripada itu layanan penguasaan konten yang guru pembimbing lakukan.

Berdasarkan informasi yang peneliti dapatkan Jumat 13 November 2020 pukul 09.15 WITA yang didapatkan dari guru bimbingan disekolah, peneliti menemukan fenomena pada SD Negeri 23 Batara Kecamatan Wara Kota Palopo bahwa siswa yang sering terasa bosan saat mengikuti pelajaran. Dibuktikan dengan siswa yang kurang fokus mendengarkan apa yang diajarkan guru, jarang mengerjakan tugas sekolah, saat ada materi yang tidak dimengerti siswa diam tidak bertanya, mengganggu teman lain saat berlangsungnya suatu proses pembelajaran di kelas, berbicara dengan teman yang bahkan tidak mau mengikuti pelajaran. Maka itu peneliti tertarik untuk mengangkat judul "Upaya Meningkat Minat Belajar Siswa Melalui Pemberian Bimbingan Belajar Menggunakan Model Pembelajaran Discovery Learning Pada Kelas IV SD Negeri 23 Batara Kecamatan Wara Kota Palopo.

\section{METODE}


Penelitian ini merupakan pendekatan kuantitatif. Pendekatan kuantitatif, yaitu penelitian yang berdasarkan pada angka, seperti menghitung hasil evaluasi siswa dalam pembelajaran. (Sugiyono, 2013:37) Jenis penelitian yang digunakan adalah yaitu penelitian tindakan kelas (PTK) aksi yang berulang-ulang untuk memperbaiki proses belajar mengajar dikelas. Hal ini sebagaimana yang diungkapkan oleh kemmis dan tagart menyatakan bahwa: Proses penelitian tindakan ialah sebuah siklus atau proses daur ulang yang terdiri dari empat aspek fundamental, diawali dari aspek mengembangkan perencanaan, lalu melakukan tindakan sesuai dengan rencana, observasi/pengamatan terhadap tindakan, dan diakhiri dengan melakukan refleksi.

Langkah-langkah tindakan yang dilalui merupakan kerja yang berulang (siklus) sehingga diperoleh pembelajaran yang dapat meningkatkan minat belajar pada siswa kelas IV SD Negeri 23 Batara Kecamatan Wara Kota Palopo dikatakan minat belajar jika terjadi perubahan dalam dirinya yang meliputi aspek kognitif, efekif, dan psikomotor.

Berdasarkan pemahaman terhadap tindakan sebagaimana yang telah dipaparkan diatas bahwa secara sederhana PTK dapat diartikan sebagai penelitian tindakan kelas (action research) yang dilakukan untuk memperbaiki kualitas proses dan hasil belajar siswa.

Penelitian ini dilaksanakan untuk meningkatkan minat belajar siswa melalui pemberian belajar dengan model discovery learning pada pelaksanaannya, penelitian ini dilaksanakan secara kolaborasi antara peneliti dengan guru. Dalam hal ini peneliti berkolaborasi dengan guru dengan tujuan agar lebih mudah dan teliti dalam kegiatan observasi tersebut. Jusmawati, dkk (2021).

Fokus Penelitian, Penelitian ini dilakukan siswa kelas IV SD Negeri 23 Batara Kecamatan Wara Kota Palapo berfokus pada aspek yaitu: Minat Belajar adalah minat belajar siswa dalam pembelajaran dengan menggunakan model discovery learning atau disebut juga dengan model yang berpusat pada siswa merupakan model yang mengharuskan para siswa menemukan suatu gagasan rmengenai materi yang sudah disampaikan oleh pengajar.

Model ini juga dikatakan sebagai tata cara atau jalan pengajaran menuju tujuan yang disesuaikan dengan indikator yang telah ditentukan dalam perencanaan pelaksan aan pembelajaran. Oleh karena itu, model pembelajaran harus direncanakan terlebih dahulu secara benar-benar. Sehingga, sebaiknya guru menggunakan model yang tepat menunjang kegiatan belajar, sehingga dapat dijadikan sebagai alat yang efektif untuk mencapai tujuan pengajaran. Setting Penelitian tindakan kelas dilaksanakan di SD Negeri 23 Batara Kecamatan Wara Kota Palopo, tentang Meningkatkan Minat Belajar melalui pemberian bimbingan model discovery learning Waktu PenelitianPenelitian tindakan kelas ini dilaksanakan di kelas V pada semester ganjil di SD Inpres Borong Jambu II Kota Makassar.

Subjek penelitian ini adalah siswa kelas V SD SD Inpres Borong Jambu II Kota Makassar dengan jumlah siswa 21 siswa, dimana jumlah siswa laki-laki 9 siswa dan jumlah siswa perempuan 12 siswa.

Dalam penelitian Tindakan kelas dalam penelitian tindakan kelas ini menggunakan model tindakan menurut Kemmis dan Taggart yaitu rancangan penelitian berdaur ulang (siklus) yang mencakup: (1) tahap perencanaan, (2) tahap pelaksanaan tindakan, (3) tahap observasi dan (4) tahap refleksi. Adapun skema dari model penelitian ini, yaitu sebagai berikut:

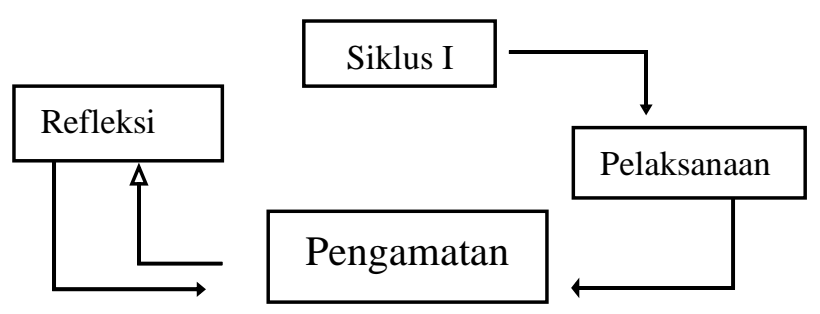




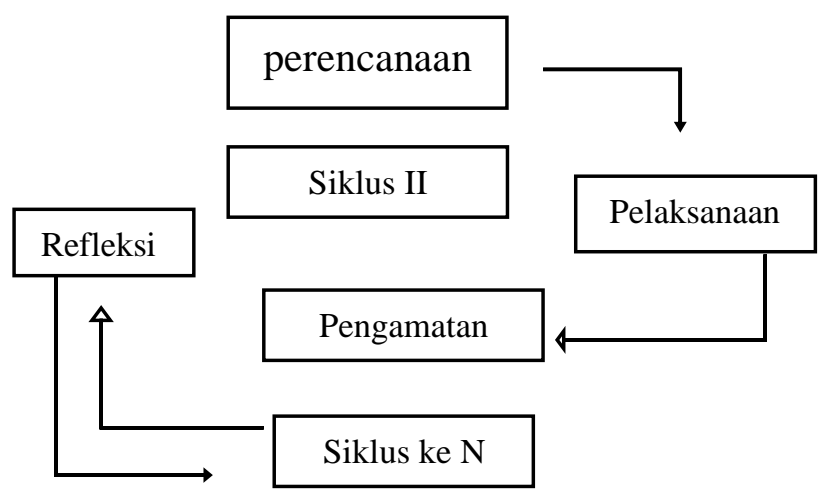

Lembar Observasi merupakan catatan yang menggambarkan tingkat aktivitas siswa dalam proses pembelajaran secara daring, aktivitas siswa dikatakan berhasil jika mencapai skor 80 sudah mencapai kriteria yang telah ditentukan. Teknik pengumpulan data yang digunakan dalam penelitian ini adalah observasi dan angket. Data diambil dari hasil catatan atau obervasi penelitian terhadap siswa selama pembelajaran berlangsung.

Sedangkan untuk mengumpulkan data minat belajar siswa, dilakukan angket yang diberikan pada setiap siklusnya.Indikator keberhasilan dalam penelitian tindakan kelas ini dinyatakan berhasil apabila adanya peningkatan minat belajar disetiap siklusnya. Penelitian ini dinyatakan behasil jika $80 \%$ siswa mancapai nilai sesuai dengan nilai yang ditetapkan pada indikator keberhasilan.

\section{HASIL DAN PEMBAHASAN}

\section{Hasil}

Penelitian dilaksanakan di SD Negeri 23 Batara Kecamatan Wara Kota Palopo yang perupakan salah satu lembaga pendidikan. Mempunyai 18 ruangan kelas untuk kegiatan belajar mengajar, 1 ruangan kepala sekolah, 1 ruangan guru, 1 ruangan perpustakaan. Subjek penelitian ini adalah siswa kelas IV yang berjumlah 21 siswa, terdiri dari 9 siswa laki-laki dan 12 siswa perempuan. SD Negeri 23 Batara Kecamatan Wara Kota Palopo dengan system pembagian waktu belajar dari 07:30 - 12:15 WITA di SD Negeri 23 Batara Kecamatan Wara Kota Palopo.

\section{Pelaksanaan siklus I}

Pelaksanaan penelitian dilakukan selama empat kali dalam setiap siklus dengan durasi 3x35 menit. Pertemuan I pada siklus 1 dilaksanakan pada hari rabu, 5 mei 2021 pukul 7:3009:30, sedangkan pertemuan 2 dilaksanakan pada hari kamis, 6 mei 2021 pukul 07:30-09:30 sedangkan pertemuan ke 3 di laksanakan sabtu, 8 mei 2021 pukul 07:30- 09:30 sedangkan pertemuan ke 4 di laksanakan senin, 10 mei 2021 dengan jumlah siswa 26 siswa. Dengan menggunakan model discovery learning untuk meningkatkan hasil belajar siswa pada mata pelajaran. Pada pertemuan pertama, kedua, ketiga dan ke empat kegiatan awal sebelum memulai pembelajaran terlebih dahulu guru menjelaskan langka langkah pembelajaran yang dilaksanakan dan menyiapkan perangkat seperti berikut :

1) Menetapkan waktu mulai penelitian tindakan kelas yaitu pada semester genap.

2) Menelaah kurikulum yang sedang berlangsung tentang materi pelajaran yang akan dibahas. Guna untuk menyiapkan perangkat pembelajaran yang disesuaikan dengan kurikulum pada kelas IV. Pengkajian dilakukan pada materi pelajaran, alokasi waktu, indikator pencapaian serta menyusun 
rencana pelaksanaan pembelajaran (RPP) sesuai dengan indikator yang telah ditetapkan dan langkah-langkah model pembelajaran Discovery Learning.

3) Mempelajari materi yang akan diajarkan dari berbagai sumber.

4) Menyiapkan angket minat belajar, lembar observasi siswa dan guru, yang ingin dicapai pada saat melaksanakan tindakan.

5) Konsultasi dengan guru wali kelas IV untuk menentukan kategori kemampuan siswa.

Peneliti memulai pembelajaran dengan menggunakan media Zoom dengan doa bersama pada kegiatan aperesepsi yaitu apersepsi guru menyampaikan tujuan pembelajaran. Kemudian peneliti menyampaikan materi pembelajaran berupa video pembelajaran.

Guru menyampaikan kembali materi yang akan dipelajari pada hari ini tema cita-citaku dan sub tema aku dan cita-citaku. Kemudian guru menanyakan kepada siswa tentang cita-cita mereka, lalu beberapa siswa menjawab pertanyaan tersebut, guru menunjuk salah satu siswa membaca teks puisi berjudul cita-citaku yang disajikan dalam buku siswa. Setelah materi dijelaskan, siswa diberikan penjelasan oleh guru untuk menyimak materi yang telah di sajikan yaitu aku dan cita-citaku.

Setelah materi dijelaskan peneliti diberi kesempatan kepada siswa untuk menanyakan materi yang belum jelas. Selanjutya peneliti memberikan tugas yang berbubungan dengan materi yang telah di berikan sebelumnya.

Diakhir pembelajaran peneliti memberikan penguatan tentang materi dan tugas yang telah dikerjakan serta memberi motivasi kepada siswa untuk belajar lebih rajin dalam belajar. Peneliti juga melakukan pemberian angket untuk melihat tingkat pencapaian minat belajar siswa. Pengukuran hasil minat belajar siswa dilakukan dengan mengerjakan soal pertanyaan sebanyak 25 butir soal kepada siswa. Siswa mengerjakan soal pertanyaan secara individu. Saat siswa sedang mengerjakan soal, Setelah hasil angket dikerjakan dan dikumpulkan, guru memberi penguatan kepada siswa agar lebih rajin belajar dirumah sepaya menjadi anak kyang pandai dan bisa dalam segala hal.

Kemudian guru menutup pembelajaran dan memberi salam. Selanjutnya, guru mengoreksi hail pekerjaan siswa. Dari hasil angket didapat data yang berupa angka-angka mengenai jumlah yang diperoleh siswa.

Hasil yang diperoleh di atas merupakan hasil pengamatan yang dilakukan observer selama kegiatan belajar berlangsung secara online. Hasil observasi pertemuan keempat terlihat jumlah siswa yang sudah memiliki peningkatan dalam proses belajar mengajar dengan jumlah skor 68 atau dalam kategori baik.

\section{Minat belajar siklus I}

Hasil belajar yang dapat dipelajari pada siklus I. nilai diperoleh keseluruhan siswa pada siklus I. Adapun nilai yang diperoleh siswa pada siklus I dapat disajikan pada tabel 4.1 di bawah ini :

Tabel 4.1 Minat Belajar Siklus I

\begin{tabular}{rccc}
\hline No. & Kategori & Skor & Frekuensi \\
\hline 1 & Sangat Tinggi & $81-100$ & 12 \\
\hline 2 & Tinggi & $61-80$ & 9 \\
\hline 3 & Sedang & $41-60$ & - \\
\hline 4 & Rendah & $21-40$ & - \\
\hline 5 & Sangat Rendah & $0-20$ & - \\
\hline Jumlah & & & 21 \\
\hline
\end{tabular}




\begin{tabular}{ll}
\hline Persentase & $68,24 \%$ \\
\hline Rata-Rata & $80,60 \%$ \\
\hline
\end{tabular}

Sumber: Lampiran 13 Halaman 103

Berdasarkan Tabel 4.1 terlihat bahwa setelah melalui proses pembelajaran yang dilakukan dengan menggunakan model Discovery Learning pada siklus I dengan empat kali pertemuan, hasil skor angket di atas siswa menjawab dengan hasil skor 81-100 sebanyak 12 orang pada kategori Sangat Tinggi dan menjawab dengan hasil skor 61-80 sebanyak 9 pada kategori Tinggi orang, maka minat belaja siswa siklus I persentasenya $68,24 \%$ mencapai rata-rata $80,60 \%$ pada penyebaran angket siklus I.

Meskipun minat belajar siswa yang diharapkan sudah tercapai sepenuhnya, dan minat belajar siswa pada siklus I telah mengalami peningkatan. Oleh karena itu, peneliti harus melakukan tindak lanjut ke siklus selanjutnya.

\section{Pelaksanaan siklus II}

Seperti halnya pada siklus I, siklus II dilakukan dalam 4 kali pertemuan 1 pada tanggal 17 mei 2021 dan pertemuan 2 pada tanggal 19 mei 2021 pada pertemuan 3 pada tanggal 22 mei 2021 dan pada pertemuan ke 4 pada tanggal 24 mei 2021 Kelas yang digunakan dalam penelitian tindakan kelas ini sama dengan siklus I, yaitu kelas IV dengan jumlah siswa 21, sedangkan yang hadir pada saat pembelajaran siklus II berlangsung hadir semua dengan total 21 siswa. Pembelajaran yang dilakukan guru sesuai dengan rencana pelaksanaan pembelajaran (RPP) yang disusun sebelum penelitian dilaksanakan. Sedangkan peneliti bersama observer melakukan observasi. Tema yang diberikan cita-citaku, sub tema hebatnya cita-citaku.

Kegiatan diawali dengan salam pembukaan doa bersama dan dilanjutkan dengan melakukan apersepsi, selanjutnya guru penyampaikan Kembali kepada siswa tentang cita-cita mereka dan manfaatnya bagi kehidupan di sekitarnya, Setelah itu siswa mencermati teks puisi dengan judul "Hidupku Penuh Warna". Guru menggunakan kegiatan ini untuk mengukur pengetahuan siswa tentang isi puisi dan keterampilan siswa dalam mengidentifikasi ciri-ciri puisi. Setelah itu guru memberikan kesempatan kepada siswa jika ada yang mau ditanyakan. Ketika tidak ada lagi pertanyaan, guru mengajak siswa mengulang kembali pembelajaran pada hari ini, untuk mengetahui sejauh mana siswa memahami pelajaran tersebut.

Pada pertemuan selanjutnya pada tanggal 22 mei 2021, guru mengingatkan kembali kepada siswa mengenai materi yang telah dipelajari pada pertemuan sebelumnya. Setelah peneliti menjelaskan materi siswa diminta untuk menanyakan hal-hal yang belum dipahami dari penjelasan peneliti.

Pada akhir pembelajaran peneliti bersama dengan siswa membuat kesimpulan materi yang telah dipelajari hari ini. Siklus II diakhiri dengan kegiatan pengisian angket dengan memberikan soal pertanyaan berjumlah 25 butir soal untuk mengetahui kemampuan siswa dalam minat belajar siswa pada siklus II.

\section{Minat Belajar siklus II}

Tabel 4.4 Minat Belajar Siklus II

\begin{tabular}{cccc}
\hline No & Kategori & Skor & Frekuensi \\
\hline 1 & Sangat Tinggi & $81-100$ & 12 \\
\hline 2 & Tinggi & $61-80$ & - \\
\hline 3 & Sedang & $41-60$ & - \\
\hline 4 & Rendah & $21-40$ & - \\
\hline 5 & Sangat Rendah & $0-20$ & - \\
\hline Jumlah & & & 21 \\
\hline Persentase & & & $80,85 \%$ \\
\hline
\end{tabular}




\begin{tabular}{|c|c|}
\hline Rata-Rata & $0505 \%$ \\
\hline
\end{tabular}

Sumber: Lampiran 26 Halaman 132

Berdasarkan Tabel 4.4 terlihat bahwa setelah melalui proses pembelajaran menggunakan model Discovery Learning dalam siklus II dengan empat kali pertemuan, hasil skor angket di atas siswa menjawab hasil skor 81-100 sebanyak 21 orang pada kategori Sangat Tinggi, maka minat belajar siswa pada siklus II persentasenya $80,85 \%$ mencapai rata-rata $95,95 \%$ pada penyebaran angket akhir siklus II. Oleh karena itu, minat belajar siswa meningkat sesuai dengan indikator keberhasilan yang ditetapkan lebih dari 60 dan dikategorikan Sangat Tinggi.

\section{Pembahasan}

Penelitian ini dilakukan pada dua siklus, pada setiap siklus terdapat 4x pertemuan. Adapun yang dilakukan pada siklus I dan II untuk meningkatkan minat belajar melalui pemberian bimbingan belajar dengan menggunakan model discovery learning pada kelas IV SD Negeri 23 Batara Kecamatan Wara Kota Palopo

Dalam penerapan model discovery learning minat belajar siswa pada siklus I Dan II mengalami peningkatan. Indikator minat belajar siswa terdapat dalam penyebaran angket. Minat belajar siswa dengan persentase pada siklus I 68,24\% mencari rata-rata $80,60 \%$ sedangkan pada siklus II persentasenya sebesar $80,85 \%$ mencari rata-rata $95,95 \%$ mengalami peningkatan.

Peningkatan kedua siklus tersebut yaitu $15,35 \%$ hal ini dapat dilihat dari peningkatan jumlah skor siswa pada siklus I, 3 siswa dapat dikatakan kurang berminat dan pada siklus II, 3 siswa tersebut minat belajar meningkat dan hamper semua 21 siswa yang memiliki minat belajar yang baik pada siklus II. Dari Siklus I dan II pada minat belajar siswa sudah mencapai 15,35\%, dan sudah mencapai kriteria keberhasilan, jadi dalam penelitian ini peneliti tidak merencanakan tindakan berikutnya.

Berdasarkan hasil peneliti tersebut diatas, maka untuk selanjutnya model Discovery Learning dapat diterapkan dalam pembelajaran di SD Negeri 23 Batara Kecamatan Wara Kota Palopo karena terbukti dapat meningkatkan minat belajar siswa kelas IV.

\section{SIMPULAN DAN SARAN}

Berdasarkan hasil penelitian tindakan kelas (PTK) yang telah dilaksanakan di SD Negeri 23 Batara Kecamatan Wara Kota Palopo menggunakan model discovery learning maka, dapat disimpulkan sebagai berikut:

1. Untuk meningkatkan minat belajar siswa maka disarankan bagi guru untuk menggunakan model Discovery Learning dapat meningkatkan minat belajar siswa SD Negeri 23 Batara Kecamatan Wara Kota Palopo.

2. Bagi siswa kelas IV SD Negeri 23 Batara Kecamatan Wara Kota Palopo dapat lebih aktif dalam proses pembelajaran karena dengan keaktifan siswa dalam pembelajaran dan membantu siswa untuk lebih memahami materi yang diberikan oleh guru sehingga dapat meningkatkan minat belajar.

3. Dalam model Discovery Learning, guru diharapkan melaksanakan sesuai dengan tahap-tahap yang telah ditentukan mulai dari tahap perencanaan, pelaksanaan tindakan sampai tahap refleksi untuk keefektifan pembelajaran.

\section{DAFTAR RUJUKAN}

Arikunto, S. 2013. Prosedur Penelitian (Suatu Pendekatan Praktik). Jakarta : Rieneka Cipta.

Budiningsih, Asri. 2012. Belajar dan Pembelajaran. Jakarta : Rieneka Cipta. 
Depdikbud. 1995. Panduan Pelayanan Bimbingan \& Konseling Bimbingan. Jakarta: Departemen Pendidikan dan Kebudayaaan : Dirjend Dikdasmen.

Dimyati, Johni. 2013. Metodologi Penelitian Pendidikan \& Aplikasinya. Jakarta : Prenada media Grup. Herlina. 2012. Minat Belajar. Jakarta : Bumi Akrasa.

Hikmawati Fenti. 2010. Bimbingan Konseling. Jakarta: Pt Rajagrafindon Persada.

Hosnan. 2013. Pendekatan Saintifik dan kontekstual dalam pembelajaran Abad 21. Bogor: Ghalia Indonesia.

Jusmawati, J., Satriawati, S., Akhiruddin, A., Rahman, A., Arsyad, N., \& Irman, R. (2021). Developing mathematics learning devices based on creative problem solving model in elementary school. Linguistics and Culture Review, 5(1), 406-421.

Kuder, S. Jay., Hasit, C. 2002. Enhancing Literacy ForAll Students. USA : Pearson Education inc.

Kurniasih, Imas. 2014. Penelitian Tindak Kelas. Jakarta : Kencana.

Mulyasa. 2017. Guru dalam Implementasi Kurikulum 2013. Bandung : PT Remaja Rosdakarya.

Nurihsan Achmad Junika. 2006. Bimbingan \& Konseling. Bandung : PT. Refika

Nursalim Mochamad. 2015. Pengembangan Profesi Bimbingan dan Konseling. Jakarta : Erlangga.

Sanjaya. 2009. Teknik Analisis Data. Surakarta : Universitas Sebelas Maret.

Slameto. 2013. Minat Belajar. Jakarta : Rineka Cipta.

Sugiyono. 2015. Metode Penelitian Pendidikan. Bandung : Alfabeta.

Suherman. 2012. Bimbingan Belajar. Bandung : Universitas Pendidikan Indonesia.

Susanto, Ahmad. 2019. Teori Belajar \& Pembelajaran Di Sekolah Dasar. Jakarta : Prenada media Group.

Yasa, Gede Sedana. 2014. Bimbingan Belajar. Yogyakarta: Graha Ilmu. 